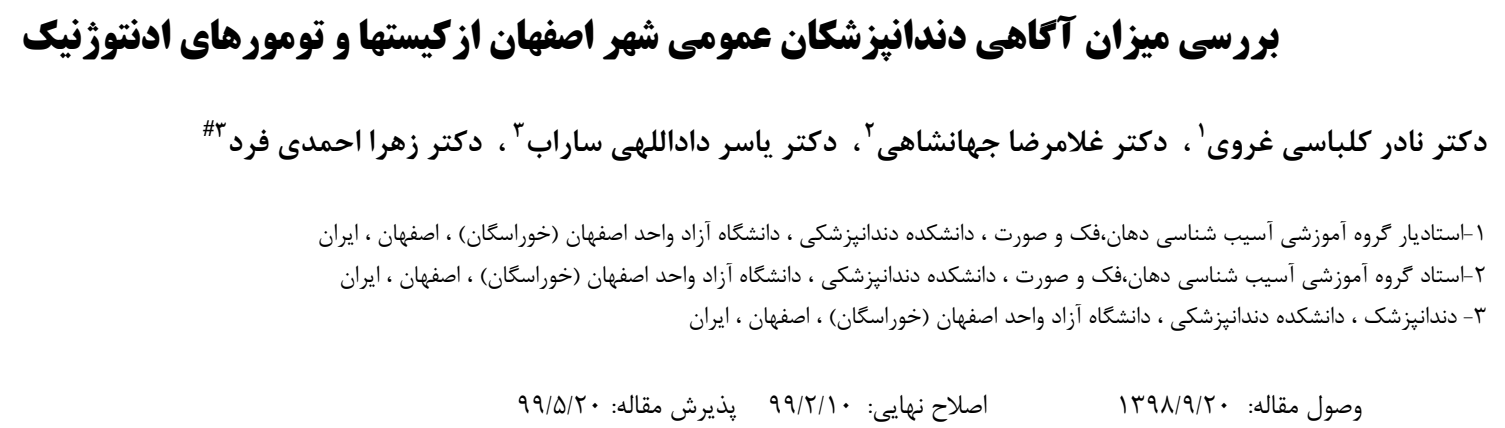

\title{
The Evaluation of: General Dental practitioner Knowledge in Isfahan about Odontogenic cyst and tumor
}

\author{
Nader Kalbasi Gharavi ${ }^{1}$,Gholam Reza Jahan Shahi ${ }^{2}$,Yaser Dadellahi Sarab ${ }^{3}$,Zahra Ahmadifard ${ }^{3 \#}$ \\ ${ }^{1}$ Assistant Professor, Oral and Maxillofacial Pathology Dept, School of Dentistry, Isfahan (Khorasgan) Branch, Islamic Azad \\ University, Isfahan, Iran \\ ${ }^{2}$ Professor, Oral and Maxillofacial Pathology Dept, School of Dentistry, Isfahan (Khorasgan) Branch, Islamic Azad University, \\ Isfahan, Iran \\ ${ }^{3}$ Dentist, School of Dentistry, Isfahan (Khorasgan) Branch, Islamic Azad University, Isfahan, Iran
}

\section{Abstract}

Received: December 2020

; Accepted: July 2020

Background and Aim: Odontogenic cysts are divided into different types of developmental and inflammatory growth.Odontogenic tumors comprise a complex group of lesions. The aim of this study was to evaluate the knowledge of general dentists working in Isfahan of common odontogenic cysts and tumors.

Material and Methods: The statistical population of Isfahan general dentists and the number of samples was 199.Standard self-made questionnaires were used to assess the level of knowledge of dentists and paired analytical tests $\mathrm{T}$ and $\mathrm{T}$ and analysis of variance were used for statistical evaluations.

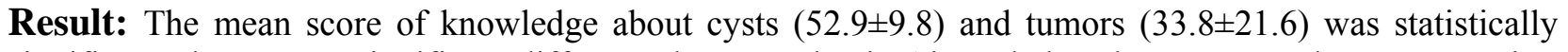
significant,There was a significant difference between dentists' knowledge about cysts and tumors,Dentists were moderate for cysts and poor for tumors.Independent t-test showed that dentists' knowledge score about cysts and tumors was not significantly correlated with gender $(\mathrm{P}=0.22, \mathrm{P}=0.21)$. One-way ANOVA showed that dentists' knowledge about cysts and tumors was not significantly correlated with the university of study $(\mathrm{P}=0.73, \mathrm{P}=0.49)$, The results also showed that the mean score of dentists' knowledge was significantly correlated with the year of graduation $(\mathrm{P}=0.001, \mathrm{P}=0.04)$ and the highest score was for graduates 69-80years and the lowest score was for graduates $86-90$ years.

Conclusion:The results showed that the level of knowledge of most dentists in Isfahan about cysts was moderate and that of tumors was poor. The mean score of dentists' knowledge about cysts was significantly higher than their knowledge of tumors was significantly correlated with the graduation year so older graduates were more aware about cysts and tumors.

Key words: Odontogenic cysts, Odontogenic tumors,Knowledge

*Corresponding Author: zahra.ahmadifard93@gmail.com

J Res Dent Sci. 2020; 17 (3) : 229-235 
سابقه و هدف: كيستهاى ادنتوزنيك به انواع رشد نموى والتهابى تقسيم ميشوند.تومورهاى ادنتوزنيك شامل يك گروه پِيجيده

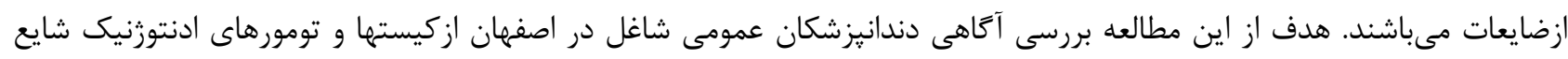
درحفره دهان مىباشد. مواد و روشها: جامعه آمارى دندانيزشكان عمومى اصفهان و تعداد نمونه مورد بررسى 199 نفر بود. جهت ارزيابى سطح آكاهى

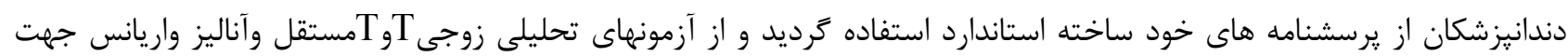

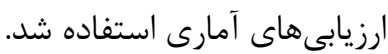

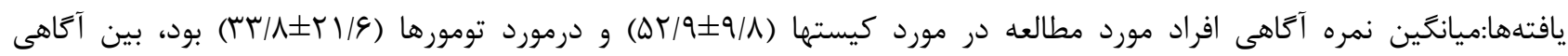

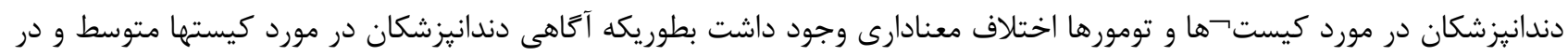

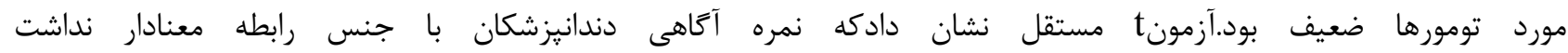

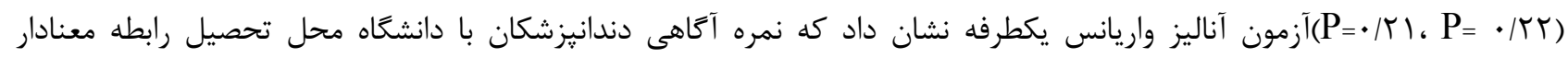

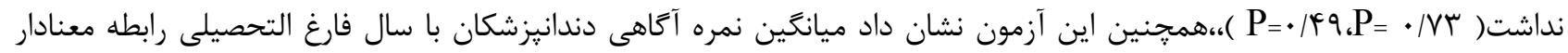

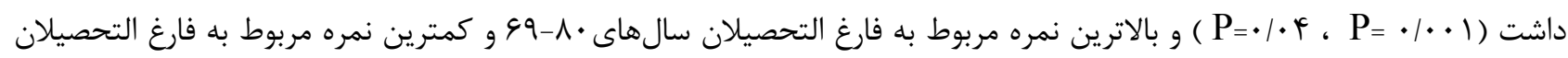

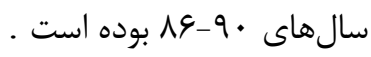
نتيجهكيرى: نتايج نشان داد كه سطح آكاهى اكثر دندانيزشكان شهر اصفهان در مورد كيست ها متوسط و در مورد تومورها ضعيف

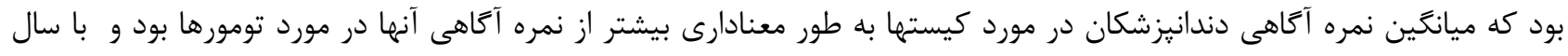

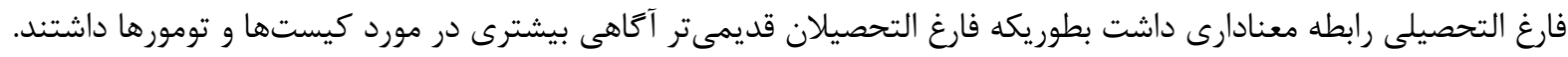
كليد وازه ها: كيست هاى ادنتوزنيك، تومورهاى ادنتوزنيك،علم

اتصال دارد)". كيست رويشى (eruption cyst) نوع خاصى مقدمه: ازكيست دانتى زوراست كه در بافت نرم روى استخوان آلوئول

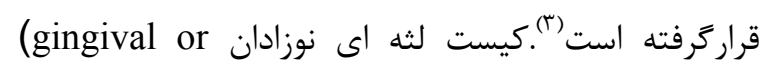
Salveolar cyst of the newborn) است كه بصورت پِايولهاى سفيدرنگ كوجى و معمولا متعدد روى نقاط يوشاننده زوائدآلوئولى نوزادان به خشمه مى خهورند (') (') كيست لثه اى بالغين (gingival cyst of adult) رشدى تكاملى است كه بر خلاف كيست لثه اى نوزادان شايع

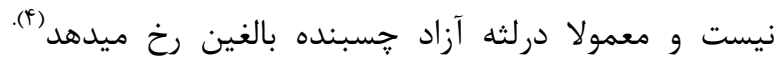
كيست يريودنتال طرفى كيست رشدى تكاملى غيرشايعى

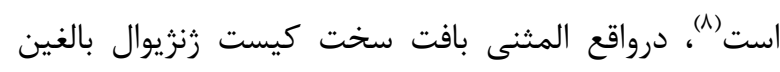

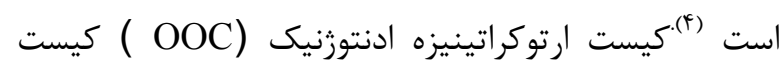
رشدى تكاملى است كه فقط از از نظر هيستوياتولوزيك التونيك

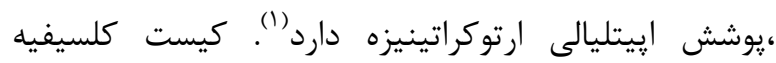

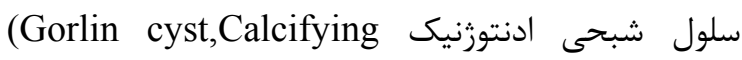
كيست رشدى تكاملى نادرى است كه كيستها و تومورهاى ادنتوزنيك شامل يك گروه گسترده ازضايعات فكين و مخاط يوشاننده آن ميباشد.كيست هاى ادنتوزنيك به انواع رشد نموى والتهابى تقسيم بندى ميشوند. شايعترين كيست ادنتوزنيك التهابى،كيست راديكولار است

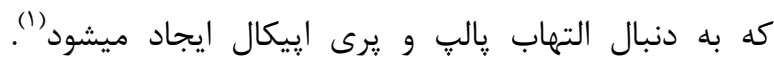

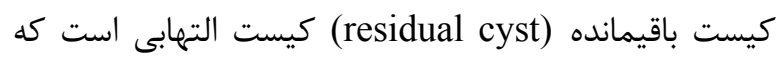

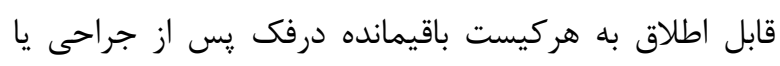
كشيدن دندان ميباشد ولى معمولا به كيستهاى راديكولار باقيمانده در فك يس از خارج كردن دندانهاى عامل اطلاق

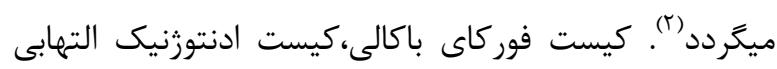
غير شايع است كه بطور اختصاصى در قسمت باكال دندان مولر اول دائمى بروز ميكند، (1). كيست دانتى زورو (فوليكولار) كيست رشدى تكاملى است كه يس از كيست راديكولر،

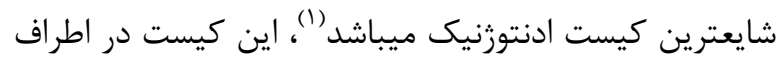

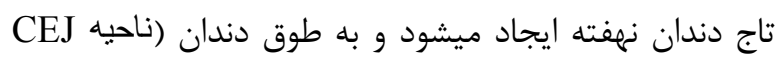


كيست ها و تومورهاى ادنتوزنيك ، و همجنين ميزان آكاهى دندانيزشكان از بيمارى هاى ديكر مطالعاتى انجام شده است

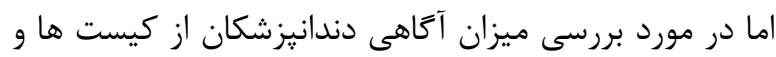
تومور هاى ادنتوزنيك با توجه به جست و جوى انجام شده در pubmed, google scholar با اين عنوان و با اين مضمون در داخل و خارج از كشور انجام

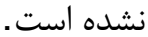
تشخيص صحيح و زود هنگام كيستها و تومورها درناحيه فكين و دهان ، حائز اهميت بالايى ميباشند و با توجه به اينكه عوارض ناشى از كيست ها و تومورهاى ادنتوزنيك در نواحى فك و دهان خود را نشان ميدهند لذا لازم است دندانيزشكان در خصوص اين علائم و خطرات آن آكاهى لازم را داشته باشند بنابراين نقش دندانيزشكان عمومى بعن بعنوان

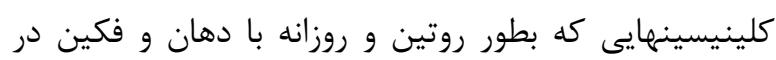
ارتباط ميباشند درشناسايى و تشخيص اوليه اين ضايعات مهمم ميباشد بنابراين هدف از اين مطالعه بررسى سطح ميزان آكاهى دندانيزشكان عمومى شاغل در سطح شهر اصفهان از كيستها و تومورهاى ادنتوزنيك بود كه توسط يرسشنامه و آزمونهاى آمارى مورد بررسى قرار كرفت.

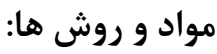

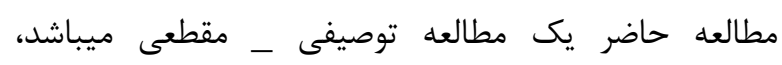
جمعيت مورد مطالعه ،دندانيزشكان عمومى شاغل در مطب هاى خصوصى و كلينيك هاى دندانيزشكى شهر اصفهان بود كه ليست آن ها از سازمان نظام يزشكى اصفهان تهيه كشته و انتخاب دندانيزشكان بصورت تصادفى ساده انجام شده بود، به 199 نفر يرسشنامه دادند و |V| نفر به سوالات يرسشنامه جواب دادند (معيار ورود به اين مطالعه، داشتن مدرى دكترى عمومى دندانيزشكى و معيار خروج ، عدم همكارى

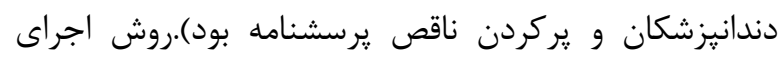
تحقيق به اين صورت بود كه به دنبال انتخاب دندانيزشكان

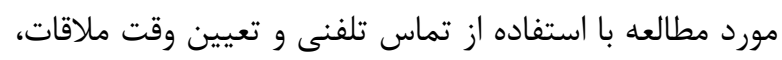
در مطب آنها حضور يافته و توضيحات لازم و جامع در مورد
بيشتر در دهه دوم اتفاق مى افتد.(ه) تومورهاى ادنتوزنيك شامل يك كروه يِيجيده از ضايعات با نا اشكال هيستوياتولوزيك و رفتار بالينى متنوعى ميباشند كه

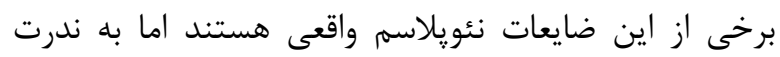

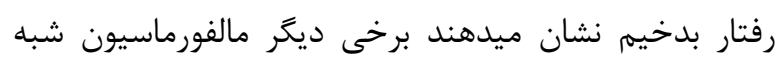

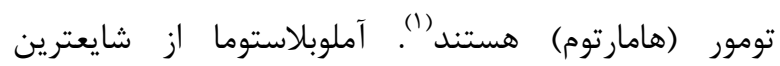

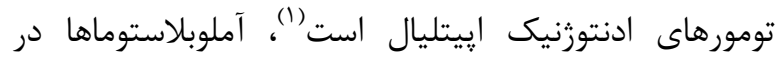
بيشتر موارد سير خوشخيم دارند،اين ضايعات به سه صورت متفاوت بالينى و راديوكرافيك بروز ميكنند اين سه نوع عبارتند از :آملوبلاستوماى توير معمولى يا مولتى سيستيك (حدود عم درصد همه موارد) ،آملوبلاستوماى تك سيستى مونى (حدود با درصد همه موارد)،آملوبلاستوماى محيطى (حدود

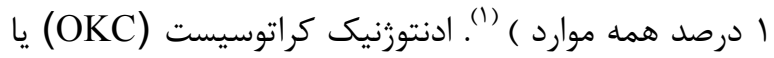

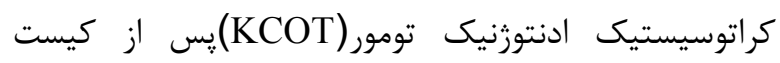
راديكولر و دانتى زور ،سومين كيست شايع در حفره دهان

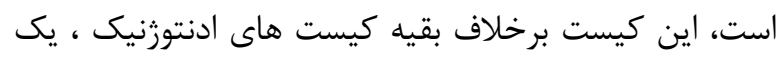
كيست واكنشى تلقى نميكردد لذا پِيشنهاد شده اين كيست بعنوان يك نئويلاسم كيستيك تلقى شده و بعنوان KCOT

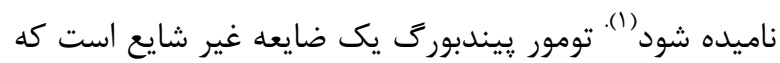
كمتر از يك درصد همه تومورهاى ادنتوزنيك را تشكيل

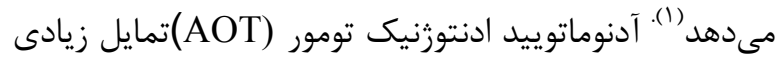
به قسمت قدامى فكين دارد و در فك بالا شايعتر است (1). ادنتوما شايعترين نوع تومورهاى ادنتوزنيك است ، ادنتوماها بيشتر انومالى تكاملى (هامارتوم) در نظر كرفته ميشوند و بله

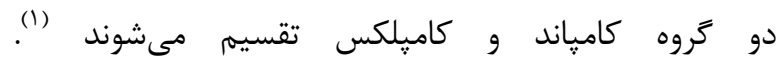

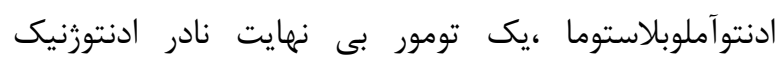

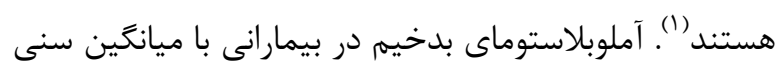
r. r سال مشاهده شده است ، برعكس كارسينوماهاى آملوبلاستيك در سنين بالاتر و در دهه ششم زندگى تشخيص داده ميشوند، متاستاز آملوبلاستوماها اغلب در ريه ها يافت ميشود ،عقده هاى لنفى گردنى ،دومين محل شايع

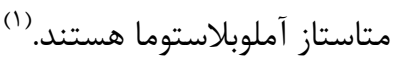
مطالعات قبلى نشان داده اند كه در خصوص ويزّكَى هاى 


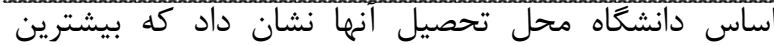
فراوانى مربوط به دانشخاه اصفهان بوده است . افراد مورد بررسى شامل فارغ التحصيلان رشته دندانيزشكى از سال 99 تا • بوده اند، كه بيشترين فراوانى دندانيزشكان(T/T FV/T) بين سالهاى ع^ تا • و فارغ التحصيل شده اند . نتايج مطالعه نشان داد كه سطح آكاهى اكثر دندانيزشكان مورد بررسى در مورد كيستها، متوسط و در مورد تومورها،

$$
\text { ضعيف است (جدول ()). }
$$

جدول ا- توزيع فراوانى سطح آكاهى دندانيزشكان در مورد

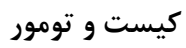

\begin{tabular}{|c|c|c|c|}
\hline درصد & تعداد & نمره اتاهى & متغير \\
\hline$|V /|$ & re & rr-•(ضعيف) & \\
\hline is & $11 \mathrm{~V}$ & Y4-49(متوسط) Y4) & كيست \\
\hline$r \notin / l$ & $i \wedge$ & 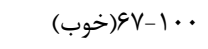 & \\
\hline$V T / F$ & lft & سז-•(ضعيف) & \\
\hline 11 & $r v$ & 4Y-4 (متوسط) & تومور \\
\hline 9 & 11 & 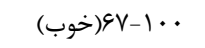 & \\
\hline
\end{tabular}

آزمون t 1 زوجى نشان داد كه ميانگين نمره آكاهى دندانيزشكان در مورد كيستها به طور معنادارى بيشتر از نمره

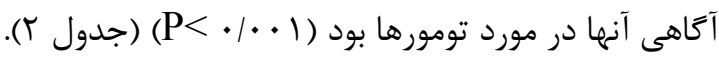

\section{جدول r- ميانكين نمره آكاهى دندانيزشكان (از +.|) در مورد}

\begin{tabular}{|c|c|c|c|c|}
\hline \multicolumn{5}{|c|}{ كيست و تومور } \\
\hline حداكثر & حداقل & انحراف & ميانكين & متغير \\
\hline & & معيار & & \\
\hline $1 \cdots$ & 1. & $9 / 1$ & $\Delta T / q$ & نمره آكاهى در مورد كيست \\
\hline $1 .$. & - & TI/9 & ג ג/זr & نمره آكاهى در مورد تومور \\
\hline
\end{tabular}

آزمون t مستقل نشان دادكه ميانگين نمره آكاهى دندانيزشكان درموردكيستها وتومورها با جنس آنها رابطه

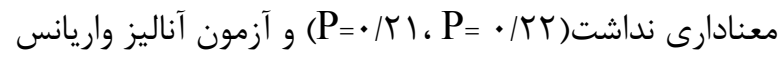
يكطرفه نشان دادكه نمره آكاهى دندانيزشكان درمورد
مطالعه حاضر به أنها داده شد در صورت تمايل أفراد به شركت در اين مطالعه جهت سنجش ميزان آكاهى، يرسشنامه در اختيار داوطلبين قرار گرفت .فرصت كافى به آنها داده و ازآنها خواسته شد تا به وقت و با حوصله كافى و بدون ذكر نام خود به سوالات مطرح شده ياسخ دهند. جهت تكميل تحقيق جوابيه ای در خصوص سوالات به دندانيزشكان داده شد، كه اين كار جنبه آموزشى داشت. در انتها نيز از دندانيزشكان خواسته شده بود كه سال فراغت از تحصيل و دانشعاه محل تحصيل خود را ذكر كنند .يس از جمع بندى داده ها و تعيين نمره يرسشنامه ها اطلاعات بدست آمده با استفاده از نرم افزار Spss و آزمون هاى آمارى t زوجى مستقل و آناليز واريانس يكطرفه مورد تجزيه و تحليل قرار گرفتند .. در اين تحقيق نيز ترسشنامه بعنوان ابزار اصلى گردآورى اطلاعات مورد استفاده قرار گرفته و جون كه يرسشنامه استانداردى بر اين زمينه وجود نداشت با نظر جمعى از اساتيد بخش آسيب شناسى دهان و بيمارى هاى دهان ، و با استفاده از كتب مرجع يرسشنامه خود ساخته اى تهيه و تنظيم گرديد كه شامل ·r سوال بود .جهت تاييد روايى برسشنامه از راهنمايى هاى اساتيد محترم بخش آسيب شناسى دهان و بيمارى هاى دهان كمك گرفته شد و براى تاييد پايايى :رسشنامه در ابتداى مطالعه با استفاده از ضرايب آزمون آلفاى كرونباخ ،تعداد • † عدد از „يرسشنامه با نظر مشاور محترم آمار مورد آزمون قرار گرفت و مقدار ضريب آلفا براى سوالات يرسشنامه بيشتر از VD/ • بود كه نشان دهنده اين است كه ״رسشنامه از يايايى قابل قبولى برخوردار است. داده ها با استفاده از آمار توصيفى به صورت فراوانى و درصد بيان شد و از آزمون تحليلى T-test جهت مقايسه داده ها

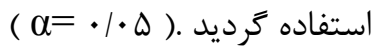

يافته ها

در مجموع 199 نفر مورد مطالعه قرار گرفتند كه از بين آنها

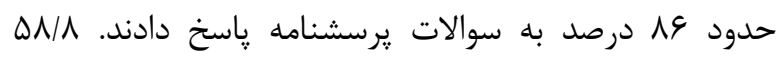
درصد (IV نفر) دندانيزشكان مورد بررسى آقا و آ آدرصد آنها(N نفر) خانم بوده اند. توزيع فراوانى دندانيزشكان بر 
سال هاى 99 تا •^ و كمترين نمره مربوط به فارغ التحصيلان بين سال هاى §م تا • 9 بوده است(جدول ؟).
كيستها و تومورها بادانشكاه محل تحصيل آنها رابطه معنادار نداشت ( آزمون آناليز واريانس يكطرفه نشان دادكه ميانكين نمره

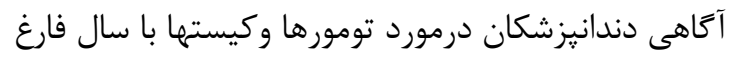

جدول r- ميانكَين نمره آكاهى دندانيز شكان در مورد كيست و تومور به تفكيك سال فارغ التحصيلى آنها

\begin{tabular}{|c|c|c|c|c|c|}
\hline & $91-94$ & $\wedge 9-q$. & $\Lambda 1-\Lambda \Delta$ & $4-\Lambda$. & متغير \\
\hline Pvalue & ميانكَين \pm انحراف معيار & ميانكين \pm انحراف معيار & ميانكَين \pm انحر اف معيار & ميانكين \pm انحراف معيار & \\
\hline & $1 \cdot / \Delta \pm \Delta \leftarrow / V$ & $9 / 9 \pm r q / q$ & $\Lambda / 9 \pm \Delta) / \Lambda$ & $19 / \% \pm 91 / 1$ & كيست \\
\hline$\cdot / \cdot \cdot 1$ & $r / / 9 \pm r q / 4$ & $19 / \Delta \pm \Gamma \Delta / \Delta$ & $r \Delta / q \pm \psi \cdot / r$ & $r \Delta / V \pm \Delta$. & تومور \\
\hline
\end{tabular}

همجنين ميانگين نمره آكاهى دندانيزشكان در مورد كيست

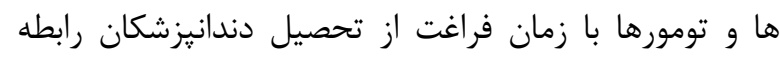

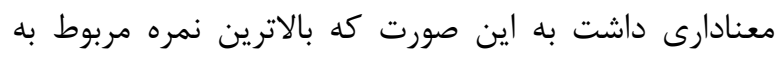
فارغ التحصيلان بين سال هاى 99 تا •1 و كمترين نمره مربوط به فارغ التحصيلان بين سال هاى عه تا • وبوده است كه ممكن است تجربه بالاتر دندانيزشكان قديمى تر ، سبب

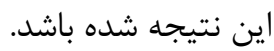
در مطالعهى سر آبادانى و همكاران بيان شد كه ميزان آكَاهى

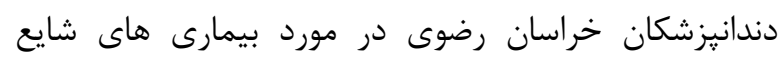

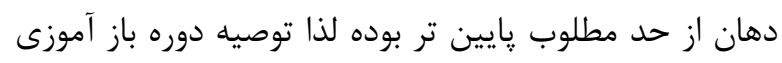
بيشترى در زمينه بيمارى هاى دهان براى دندانيزشكان بايد

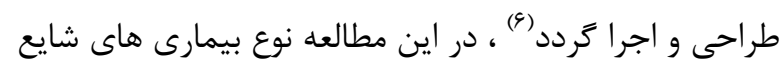
دهان و همجنين ارتباط ميزان آكاهى با دانشكاه محل تحصيل، جنس، زمان فراغت از تحصيل مشخص نشده است

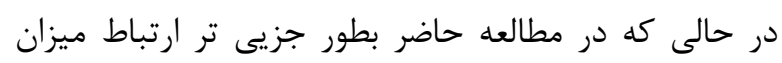
آكاهى با هنين فاكتورهايى بررسى شده است و در خصوص

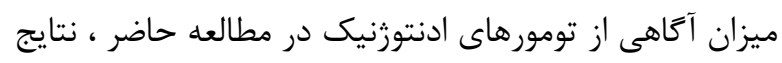

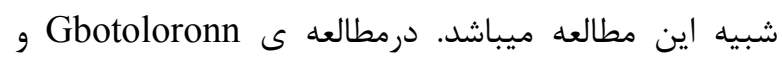

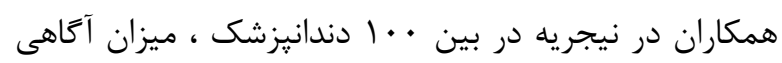

با توجه به اينكه عوارض ناشى از كيست ها و تومورهاى ادنتوزنيك در نواحى فك و دهان خود را نشان ميدهند لذا

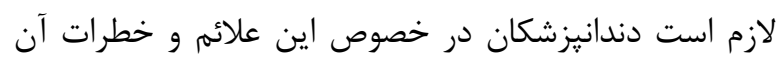

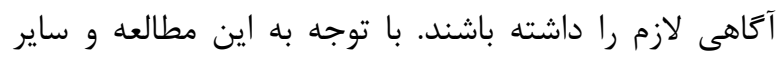

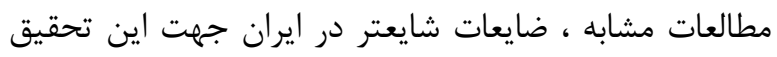
انتخاب شدند ،جنانجه نتايج نشان داد ميانگين نمره آكاهى دندانيزشكان عمومى شاغل در مطب ها و كلينيك هاى خصوصى شهر اصفهان در مورد كيست هاى ادنتوزنيك متوسط(M/A

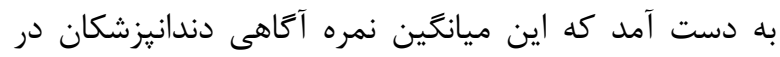

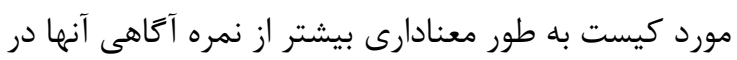

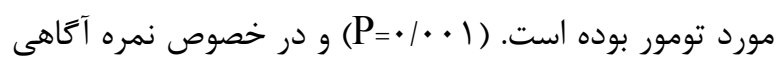
دندانيزشكان در مورد كيست و تومور در ارتباط با دانشعاه

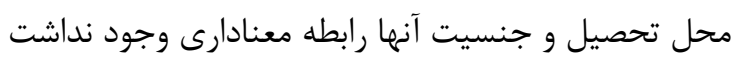

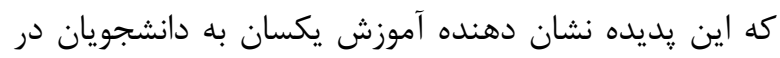
كليه دانشكده هاى دندانيزشكى در سطح كشور مى باشد و التحصيلى آنها رابطه معنادار داشت ( و در هر دو مورد بالاترين نمره مربوط به فارغ التحصيلان بين 


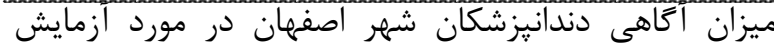
شمارش كامل خون در ميان فارغ التحصيلان رشته دندانيزشكى صورت گرفت ، يافته هاى مطالعه نشان دادند كه

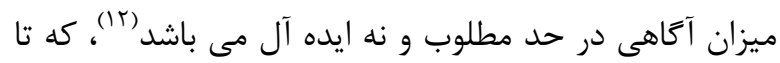
حدودى يافته هاى اين مطالعه درباره ميزان آكَاهى با يافته هاى ما در مورد ميزان آكاهى درباره كيست مشابه و درباره تومور متناقض ميباشد و توجه بيشتر به آموزش اصول یايه و اوليه در دانشكده هاى دندانيزشكى جهت افزايش سطح آكاهى دندانيزشكان ضرورى به نظر مى رسد. در مطالعه اى كه توسط آلاغبالى و همكاران به منظور بررسى ميزان آكاهى، نخرش و عملكرد دندانيزشكان اروميه در ارتباط با سرطان دهان در سال 9^\1 انجام شد يافته هاى مطالعه نشان دادند كه ميزان آكاهى دندانيزشكان اروميه درباره سرطان دهان كافى نبوده و بين ميزان آكاهى از سرطان دهان با ميزان سال هاى فراغت از تحصيل ارتباط آمارى معنادارى ييدا شد به گونه اى كه ميانگين آكاهى

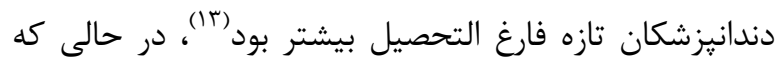
در مطالعه حاضر فارغ التحصيلان قديمى تر آكاهى بيشترى در مورد كيستها و تومورها داشتند كه شايد اين تناقض را بتوان اينگُونه توجيه كرد كه به دليل شيوع سرطان در سال هاى اخير ، آموزش بيشترى به دندانيزشكان تازه فارغ اتحصيل در خلال تشخيص سرطان دهان داده شده است.

\section{نتيجه Fيرى :}

سطح آكاهى اكثر دندانيزشكان شهر اصفهان در مورد كيست ها متوسط و در مورد تومورها ضعيف بود كه ميانخين نمره آكاهى دندانيزشكان در مورد كيستها به طور معنادارى بيشتر از نمره آكاهى آنها در مورد تومورها بود و اين ميزان آكاهى هيج ارتباط معنادارى با جنسيت و دانشعاه تحصيل آن ها نداشت اما با سال فارغ التحصيلى رابطه معنادارى داشت بطوريكه فارغ التحصيلان قديمى تر آكاهى بيشترى در مورد كيستها و تومورها داشتند.
آن ها از عوامل خطرساز سرطان دهان بسيار يايين تر از حد انتظار به دست آمد "(V)كه در اين مطالعه ميزان آخاهى از سرطان دهان بررسى شده است و ميزان آتاهى در مورد كيست و تومور مورد بررسى قرار نغرفته است ، به دليل موقعيت جغرافيايى متفاوت ممكن است نتايج متناقض به دست آيد و كمبود امكانات آموزشى به دانشجويان در نيجريه ممكن است سبب اين نتيجه شده باشد ولى نتايج اين مطالعه از نظر ميزان آكاهى يايينتر از حد انتظار شبيه نتايج مطالعه ما در خصوص ميزان آكاهى در مورد تومور ميباشد. در مطالعه اصفهانى و همكاران در خصوص ميزان آكاهى دندانيزشكان عمومى از بيمارى ايدز، ميزان آكاهى در حد متوسط بيان شد (^) كه نتايج اين مطالعه شبيه به نتايج مطالعه ما در خصوص ميزان آكاهى در مورد كيست ميباشد. در مطالعه بصير شبسترى و همكاران بيان شد كه ميزان آكاهى دندانيزشكان عمومى قزوين در مورد ييشخيرى از اندوكارديت عفونى قبل از انجام اقدام هاى دندانيزشكى در سطح متوسط قرار داشت (9)، كه نتايج اين مطالعه با نتايج مطالعه ما در خصوص ميزان آكاهى در مورد كيست مشابه ميباشد و اين مسئله نشاندهنده اين است كه ارتقاى سطح آموزش و برگزارى دوره هاى آموزشى مداوم به دانشجويان ضرورى به نظر ميرسد. در مطالعه ثقفى و همكاران بيان شد كه ميزان آكاهى دندانيزشكان مشهد در سال Ir IVV درباره سرطان دهان كافى نبوده و بايد آموزش بيشترى در قالب برنامه هاى آموزشى مداوم به آنان داده شود(·)،در سال |||+r در مطالعه يدرينى و همكاران با استفاده از يرسشنامه خودساخته در كشور برزيل ميزان آَاهى دندانِيزشكان از جَّونكى برخورد با دندان

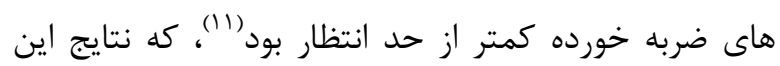
مطالعات تا حدودى با نتايج مطالعه ما بخصوص در مورد ميزان آكاهى از تومور مشابه ميباشد كه اين نكته از اين نتايج استنباط ميشود كه بايد آموزش بيشترى در قالب برنامه هاى آموزشى مداوم به دندانيزشكان داده شود. در مطالعه اي كه توسط صالحى و همكاران در سال 91٪ 9 


\section{References:}

1- Neville BW,Damm DD, Allen C,Bouquot JE. Oral and Maxillofacial Pathology. 3rd ed. Philadelphia :Saunders/Elsevier 2016;p:25-37,678-730.

2- Deyhimi P. Pathology of tooth \& odontogenic lesions. 1st edition. Isfahan University of Medical Scince2006; chapters6:164-184; chapters10:375-465.

3- Stockdale CR, Chandler NP. The nature of the periapical lesion -a review of 1108 cases. J Dent 1988;16(3):123-9.

4- Aguilo L, Cibrian R, Bagan JV, Gandia JI. Eruption cysts : retrospective clinical study of 36 cases. ASDC J Dent Child 1998;65:102-6.

5- Regezi JA, Sciubba JG. Oral pathology : clinical pathologic correlation. 4th edition. Philadelphia : WB Saunders co 2009; chapter10:237-51.

6- Sarabadani J, Pakfetrat A, Delavarian Z, EbrahimiNik Z, Nejat AH, KamelBoron AG . Knowledge and Diagnostic Skill of General Dentist in Khorasan Razavi Province Common (Iran) toward Oral Diseases 2009-10. J Mash Dent Sch 2012;36(2):113-20.

7- Gbotoloronn O, Ayodel A, Olojed A, Adamson O, Emelca $\mathrm{C}$ and amao $\mathrm{A}$. Knowledge and screening practices for oral cancer amongst goeral dental practitioners in lagos,Nigeria. African Journal of boomedical research 2014;17:20-4.

8- Esfehani M, Borhan Mojabi K, Hashemi Sh. Assessing the perspective knowledge and practice of general dentists of Qazvin about HIV infected patients. Iran J Med Microbiol 2012;6(1,2):60-1.

9- Basir-Shabestari S, Shirinbak I, Kharrazi-Gogani AR. Assessing the knowledge and practice of general dentists of Qazvin on prophylaxis against infective endocarditis prior to dental procedures (2010-2011). J Qazvin Univ Med Sci 2012;16(1):87-94. (persian)

10- Saghafi Sh, ZareMahmoodabadi R, Salehinejad J, Falaki F, Farrokhizade Sh. Evaluation of General Dentists Knowledge about Oral Cancer in MashhadIran in 2008. J Mash Dent Sch 2009;33(2):107-14.

11-Pedrini D, Panzarini S, Roberto W, Sundefeld M, Tireron A. Dentist level of knowledge of the heatmont plans for periodontal ligament injuries after dento alveolar trauma. Braz oral res 2011;25(4):30713.

12- Salehi MR, Khademi H, Khozaimeh F,Shiman F. Awareness about complete blood cell count among general dental practitioners in Isfahan. Journal of Isfahan Dental School 2011;6(5):500-5.

13- Ala Agbali A, Vosough Hossani S, Mahmoudipar F, Mahmoudi M, Janani M, Fattahi S, et al. Evaluation of urmiadentists knowledge attitude parctes about oral cancer in 2010. J urmia nurs midwifery Fac 2011;9(5):367-73.

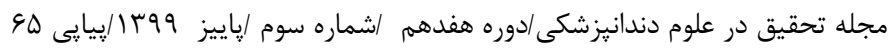

